\title{
Race, Hyper-Incarceration, and US Poverty Policy in Historic Perspective
}

\author{
Reuben Jonathan Miller* \\ University of Michigan School of Social Work
}

\begin{abstract}
In this article, I bring scholarship on welfare reform into discussion with work on crime control and racial and ethnic relations. I locate the genesis of hyper-incarceration and the moral suasion imposed on the recipients of contemporary social welfare services through the poverty policies of the Victorian era and later the postbellum south, implicating the checkered history of racial domination in the United States in the development of social welfare and criminal justice policy. I conclude by discussing the ways in which the United States has been reconfigured to facilitate these trends and of new terrain in the study of marginality in the neoliberal age. Doing so demonstrates the long-standing collusion between welfare state and criminal justice actors, identifies the racialized target of punishment and poverty management, highlights the significance of race in the development of social policy, and exhibits the importance of social welfare policy in contemporary race and ethnic relations.
\end{abstract}

\section{Introduction}

From Marx's attempts to detangle the paradox of the political economy to Weber's bleak characterization of bureaucratic rationality sociologists have long examined the contradictions of democratic governance and the punishing capacities of state institutions. This is especially true of the modern welfare state. The welfare state has been characterized as a regulatory apparatus employed to legitimate the contradictions of modern political economies (O'Connor, 1973) and a disciplinary mode of social control, fostering the expansion of precarious labor in times of prosperity, while diminishing working class solidarity during times of political unrest (Piven and Cloward, 1993). It has been implicated in bureaucratic processes of racial stratification, instantiating the stigma of dependence while ossifying the social standing of racialized groups (Lieberman 1998; Gilens 1999). More recently, sociologists have examined the contributions of social welfare policy to the dramatic, racially targeted expansion of the US prison system (Beckett and Western 2001; Wacquant 2009).

In this article, I bring the literature on welfare reform into discussion with scholarship on race, crime control, and social welfare policy. I trace the genesis of hyper-incarceration (Wacquant 2001) - the targeted policing, arrest, and imprisonment of low-income, predominantly Black inner city men - and the moral suasion imposed on the recipients of traditional social welfare services to the poverty management strategies of the Victorian era and the southern reconstruction period. I highlight public and scholarly discourses used to construct the impoverished, inner city Black family as the target of criminal justice and social welfare intervention, show the ways in which policy decisions contribute to the punishment of race across historical domain, and discuss how the United States has been reconfigured to facilitate these trends. Doing so demonstrates the long-standing collusion between welfare state and criminal justice actors, highlights the significance of race in the development of 
social policy, and exhibits the importance of social policy decision making for contemporary race and ethnic relations.

\section{Hyper-incarceration, a brief primer}

In just under 20 years, the US prison demographic shifted from $2 / 3$ White to over $2 / 3$ nonWhite (Wacquant, 2001). African-Americans, who have historically comprised just over 12 percent of the US population, now represent nearly half of all persons held under lock and key (Maurer 2006). At the same time, the number of prisoners increased sevenfold between 1980 and 2010, reaching a figure that exceeded 2.3 million at the height of incarceration during this recent and historic prison boom. Nearly half of all arrests over the last several decades have been for formal drug charges (upwards of 80 percent in some municipalities according to Lurigio, et al. 2010), with almost $2 / 3$ of all new arrests composed of Black men, most of whom were convicted for low-level drug offenses (Alexander 2009). To further complicate matters, released prisoners returning to their home communities and the prisoner reentry organizations that serve them are overwhelmingly concentrated in low-income communities of color (Miller forthcoming). As a result, more than half of the prisoners from the country's most populous urban regions are policed, arrested, returned, and provided services to rehabilitate them all within the very low-income neighborhoods they call home (Peck and Theodore 2009; Miller), raising important questions about the concentration of social disadvantage and the containment of unskilled Black laborers (Wacquant 2009).

Scholars have designated the historic prison expansion project and the overwhelming focus of criminal justice intervention within racialized districts of urban disadvantage (Sampson and Loeffler, 2010) "mass incarceration" (Western 2006), the "culture of control" (Garland 2001), "racialized mass incarceration" (BoBo and Thompson 2010), and the "New Jim Crow" (Alexander 2009). Noting the selective targeting of the criminal justice system and the concentration of criminal justice interventions within low-income communities, sociologist Loïc Wacquant designates the era of prison expansion hyper-incarceration.

It is important to note that the dramatic increase in the size and scope of the US prison system was coupled with an equally historic retrenchment of the social safety net, ushering in what scholars have described as the "punitive turn" in social welfare and criminal justice policy. Building on groundwork laid during the Reagan administration, congress passed the Personal Responsibility and Work Opportunities Reconciliation Act of 1996 (PRWORA), making good on President William Jefferson Clinton's promise to "end welfare as we know it." Through the advent of new modes of surveillance, draconian eligibility criteria, the sanctioning of non-traditional family forms, and the enforcement of stringent work requirements, this new legislation moved many dependent poor families off the "dole" as evidenced by the nearly 65 percent drop in the welfare caseload in just under a decade and onto the rolls of the lowwage labor market. PRWORA has had considerable fallout for the racialized targets of urban poverty policy. With fewer benefits and unsustainable wages, scholars have argued welfare reform helped concretize the positions of the raced targets of social policy within the lower reaches of a deindustrialized economy (Wacquant 2009; Peck 2010 and 2010; Piven and Cloward [1971] 1993).

The austere turn in social welfare policy and the punitive turn in criminal justice administration have been considered characteristic of US style neoliberalism - the dominant policy regime in the US for more than three decades. Neoliberalism has been defined as a set of clustered social and economic policies that privilege market deregulation and limited state intervention, and a logic pervading social, political, and economic discourses, the definition of social problems, and the development of social policy (Harvey, 2007; Peck, 2010; Harcourt 2011; Wacquant, 2012a, 
2012b). Following this logic, PRWORA and mass incarceration are both considered emblematic of neoliberal social and economic policy. Both followed a considerable retraction of the social state. ${ }^{1}$ In criminal justice, scholars suggest the state's commitment to rehabilitate prisoners through education and social programs was unseated by commitments to deter crime and incapacitate exoffenders (Feeley and Simon 1992; Garland 2001; Wacquant 2009). Rehabilitation has however endured in modified forms (Phelps 2011) ranging from the therapeutic interventions available within prisons and courts (Fox 1999) to the fragmented constellation of prisoner reentry services operating within prisoners' respective receiving communities (Peck and Theodore 2009; Haney 2010). Despite this, scholars widely agree that the political logics animating criminal justice administration shifted from a rehabilitative to a more punitive orientation. On the welfare front, cash benefits were significantly decreased, and welfare programs increasingly focused on behavioral modification and the veneration of work, making the poor rather than the States responsible for the mitigation of their own social problems. Thus, punishment scholars have labeled this historic moment an era of neoliberal penality, where social marginality is managed in punitive ways through welfare state and criminal justice institutions (Beckett and Western, 2001; Wacquant 2009; Harcourt 2011). A cursory examination of the demographic profiles of the prison and public welfare clientele makes this readily apparent. Blacks and Latinos represent disproportionately large shares of both the prison population and the public welfare caseload, with nearly identical rates of unemployment, negative mental health outcomes, and poverty more than half of each institution's population lives at or below just half of the US poverty line (Wacquant 2009).

The prison boom has made the United States the world leader in the global "race to incarcerate," with more people under state supervision than in any other country in the history of the world (Maurer 2006; Wacquant 2009). At the same time, welfare reform has added many poor families to the ranks of the working poor, contributing to record disparities in income, wealth, educational achievement, and mental and physiological health outcomes (Nkansah-Amankra et al., 2013).

Despite these trends, it is important to note "that the techniques of poverty management and even the disproportionate arrest and imprisonment of minority populations do not make neoliberal approaches to manage the urban poor unique" (Wacquant, 2012b). Rather, these techniques find their roots in colonial discourses on dependence, deviance, and the dangers of pauperism, the once thought to be outdated modes of racial control, and the selective enforcement of vagrancy convictions in the postbellum south. These techniques and the political logics that guide them were updated during the various "wars" on urban disadvantage: the "War on Poverty," the "War on Drugs," and what historian Michal Katz (2001) has labeled the "War on Dependence." Thus, the disproportionate arrest, sentencing, and incarceration of African-Americans particularly, along with the project of responsibilization rolled out under the banner of US neoliberalism more specifically, articulates with long-standing policies and political discourses targeting Black pauperism, Black crime, and Black dependence on the state, which reached their zenith in the regressive 1990s. These practices and the punitive trends they inspire are documented in classical sociological works (see particularly Du Bois, 1899, 1935) but have been overlooked in the extant literature on punishment and social welfare provision.

\section{Black dependence and the danger of the dole}

Scholars have analyzed the significance of US race and ethnic relations in the development and administration of the welfare state (Quadagno 1994; Casenave and Neubeck 2001; Lieberman, 1998). The history of social provision makes the significance of race, perhaps, most apparent. More than a century before the passage of New Deal policies, political 
discourses about poverty, dependence, and race culminated in profound ways, leading to the ratification of the New Poor Law Act and the concurrent passage of the Total Emancipation Act of 1834 (O'Connell, 2009, 2010). The act abolished slavery in Britain and its colonies but did not extend freedom to all slaves. In the U.S., economists of the Victorian era had already vigorously debated the role of slavery as a "barrier to the natural motive to labor" (Martin 2008; O'Connell, 2009). Freed slaves, White abolitionists, and members of the Black resistance movements in Europe and the United States struggled for abolition, while at the same time labor reformers operating in the interest of working class Whites advocated for labor rights and a sustainable wage. While labor activists openly complained of harsh workplace conditions and worker exploitation by land-owning industrial and agricultural capitalists, activists and labor reformers contended that slaves in the United States were better off than many of their constituents. Access to poor relief was rigidly policed drawing racial lines where intuitive labor coalitions may have ordinarily formed (Du Bois 1935; O'Connell 2009).

Prior to the onset of the Civil War, welfare discourses linked the fate of the slave, the freedman, and the pauper (O'Connell 2009). Poverty experts from various fields compared the living conditions and "natural inclinations" of each population, marshaling statistical analyses and the latest social scientific techniques to determine their "readiness for economic freedom" (Martin 2008; O'connell 2009). Invoking slaves "natural characteristics," Poor Law reformers contended that poor relief fostered a "slave mentality" among the White working class. Receipt of the "dole" was thought to "entitle men to all a slave's security for subsistence without his liabilities to punishment” (Kern 1998, p. 428 as quoted in O'Connell 2009), foreshadowing critiques of the "nanny state" and the "entitlement society" that would animate political discourses for nearly two centuries. At the same time, slaveholders invoked discourses from the Poor Law debates to support their contention that slaves were incapable of self-reliance and would instead end up on the incapacitating "dole" if granted freedom. Thus, the racist trope of Black dependence was used to delay freedom (and later the franchise) for Blacks, while delaying labor rights and the emergence of a formal welfare state, which arguably would have largely benefited poor White workers (Quadagno 1994). These developments have had notable consequences for the development of social welfare policy and shaped punishment and corrections in important ways.

\section{Constructing the Black vagrant}

W.E.B. Du Bois was among the first scholars to explore the relationship between social welfare policy, race, and punishment during the postbellum period. In his seminal work, Black Reconstruction in America, 1860-1880, Du Bois (1935) advanced a classical Marxist framework to understand the fates of the White and Black southern proletariat, the benefits reaped by southern states during reconstruction, and the eventual retrenchment of the Black freedman's newly acquired rights through the emergence of restrictive Black Codes and the repressive Jim Crow regime that followed. More importantly for this analysis, Du Bois underscored the importance of the advent of the US Bureau of Refugees, Freedmen, and Abandoned Lands (The Freedman's Bureau), one of the first federally administered social welfare organizations in US history, in the day-to-day lives of the Black southern proletariat (Du Bois 1935; Goldberg, 2008).

The Freedman's Bureau was established in 1865 just months before the close of the Civil War. It provided emergency food, housing, clothing, and health care for refugees, former slaves, and poor Whites in need. Amidst resistance from the unseated White aristocracy, the Bureau established a system of free public education, increased health-care access through 
the establishment of free public health clinics, and provided employment assistance for freed Blacks and their poor White, southern counterparts (Du Bois 1935; Goldberg, 2008). These initiatives were federally funded, departing from the locally funded and administered system of poor relief that existed prior to the Civil War. Along with the provision of what would now be termed public welfare, the Bureau mitigated labor disputes between White planters and Black farmers and assisted Black Civil War veterans who were systematically excluded from veterans pensions (Du Bois 1935; Goldberg, 2008; Taylor 2009).

With more than 5 percent of the total African-American population volunteering for combat during the Civil War, the special status afforded veterans due to high public regard for soldiers, and the generosity of Civil War pensions, which lifted many White families out of poverty during the period, hopes for reaching social and economic parity were high (U.S. Census Bureau, 1860, Du Bois 1935; Goldberg, 2008). In her influential work, Protecting Soldiers and Mothers: The Political Origins of Social Policy in the United States, Theda Skocpol (1992) explored the administration of Civil War pensions during the postbellum period, a time that saw at its height nearly 28 percent of the adult US population as beneficiaries. While race was not a central concern of her book, Skocpol concluded that the administration of pensions was seemingly race neutral:

\begin{abstract}
Although there is no systematic evidence about how black Union veterans fared in the pension application process compared with whites, hints from the historical record suggest that free blacks with stable residential histories in the North probably did as well as their white socioeconomic counterparts, while black veterans and survivors from the ranks of freed slaves may often have lacked the documents they needed to establish claims for pensions. (Skocpol, 1992: 138)
\end{abstract}

\title{
Regarding the "deserving" status extended to Civil War veterans, Skocpol wrote:
}

Because all who received Civil War benefits were said to have "earned" them through their own efforts (or those of their husbands and fathers), the inclusion in the same system of public care of African-Americans, native born whites, and ethnic whites was accepted by northern Americans, even in an era of open racism and ethnic bigotry ... These beneficiaries did not feel demeaned as if they were accepting "charity" or "welfare" (p. 532).

Unfortunately for freedmen, their hopes for parity would be dashed. Hollandsworth (2008) finds that there were significant barriers to Black participation in Civil War pensions. On one hand, Black veterans as ex-slaves were largely impoverished and illiterate. Subsequently, just over 31 percent of eligible Black veterans submitted pension applications. Those who served on the confederate side had an especially difficult time. They were not considered eligible for veterans' pensions until 1921 in all but one state - Mississippi. In addition, the confederate army did not regularly pay or adequately account for Black soldiers among their ranks. Black veterans had to therefore seek out their former commanding officers to sign off on their pension applications. This was compounded by racial animus in both the north and south as physicians were less likely to make recommendations for disability benefits for Black veterans than they were for their White counterparts. In addition, radical republican administrators denied the pension claims of Black veterans in swing states during election cycles. Thus, by 1890, only 39.4 percent of Black veterans' pension applications were approved (representing just 12.2 percent of all eligible Black veterans). That number increased to 45 percent of all Black applicants or just fewer than 14 percent of Black veterans by 1907 when eligibility criteria were relaxed to include old age. Conversely, 77.9 percent and 72.5 percent of the applications from White veterans were approved in 1890 and 1907, respectively. To compound matters, Logue 
and Blank (2008) found that pension payments were more generous for Whites than Blacks during that period.

With the systematic exclusion of Black veterans from pension benefits, the Bureau was able to fill crucial gaps in services for disabled would-be pensioners, taking an active role in the negotiation of labor contracts and legal matters for Black veterans and their families (Goldberg, 2008). Despite these seemingly progressive policies, the Bureau's work stigmatized its largely Black client base through policies that further inculcated negative Black stereotypes. The redistributive nature of the Bureau's policies and the racial stigma of its client base fueled considerable resistance from unseated southern democrats and republican detractors alike who called for an end to the "failed experiment" just a few years after it was established. In addition, the Bureau struggled to shake the stigma of Black dependence and the general fear of Black pauperism, causing it to embrace a focus on contract labor that derailed a burgeoning spirit of Black entrepreneurship (Du Bois 1935; Farmer-Kaiser, 2004).

\section{Welfare and punishment in the postbellum south}

The most salient function of the Bureau for contemporary social welfare policy was its promotion of low-wage labor. Due to the ongoing discourse around the nature of race and poverty, along with the supposed incapacitating character of the dole, eligibility for assistance was based on the willingness of former slaves to accept the "most visible and immediate" employment available (Du Bois 1935 as quoted in Taylor 2009). Freedmen, denied entry to the labor market along with agricultural entrepreneurship in the postbellum south, were forced to engage in sharecropping relationships on the plantations from which they were emancipated. Refusal to work, inability to cover debts incurred under the peonage system, changing jobs, or committing the slightest breach of contract were grounds for prosecution under southern vagrancy laws. Conviction as a vagrant meant lengthy terms of imprisonment under the chain gangs and convict leasing system. As a result, by the end of the 19th century, Blacks comprised more than 90 percent of the convict leasing system in a still agricultural but industrializing south (Gorman 1997). During this time, the southern prison system underwent a rapid, racially targeted expansion. Prisoners were sentenced at younger ages for longer periods of time and in exponentially greater volume. Georgia saw a tenfold increase in its prison population between 1865 and 1890. At the same time, Mississippi's prison population quadrupled, while Alabama's more than tripled (Mancini, 1978), but theses phenomenon was not new. Noting racial disproportionality in the US prison system, Beaumont et al. (1833) wrote: "We see that there is in prison, in the five states, 1 colored person out of 4 prisoners. In 1830, there was (in the same states) 1 free colored person out of 30 inhabitants."

Du Bois described similar trends in his famous work, The Philadelphia Negro: A Social Study:

In 1896 the Negroes forming 4 per cent of the population furnish 9 per cent of the arrests, but in 1850 being 5 per cent of the population they furnished 32 per cent of the prisoners received at the county prison (1899).

Along with imprisonment, poor relief was used as a way to maintain racial and ethnic domination while ossifying the racial hierarchy (O'Connell, 2009). As noted, poor relief was administered along racial lines in part to discourage working class solidarity. The construction of the Black vagrant in the public policy and scholarly discourses of the time also substantiated claims about the danger of Black dependence, the "natural inclinations" of Black workers (and by extension their families), and discouraged the administration of the "dole" to lift poor Blacks out of poverty. The most "available and immediate" work was 
instead venerated as the antidote to Black poverty in the postbellum period, even when those working conditions were predatory. Thus, the administration of social welfare policy had not only stratifying effects, contributing to the very conditions of generational poverty they sought to avoid, and a general lack of cohesion among the southern proletariat through the inculcation of racial animus via bureaucratic processes, hardening the racial hierarchy among poor workers, but also classifying effects as well, contributing to the ways in which racial categories were understood (see Wacquant, 2012a).

$\mathrm{Du}$ Bois penned Black Reconstruction in the year congress passed the Social Security Act of 1935. A surface reading of this work reveals social policy and criminal justice administration as a unified mechanism of social control. A careful reading demonstrates the long-standing collusion between social welfare and criminal justice institutions in the production and maintenance of racialized ways of being in the social world. A critical reading highlights the need for an interactional and intersectional exploration of the experience of social policy as the experiences of freed slaves were mitigated by various axis of difference (including gender, region, and local sociopolitical factors). Du Bois, for example, noted, but inadequately explored the significant differences in the experiences of poor Whites, confederate soldiers, women, and youth from those of freedmen (Farmer-Kaiser, 2004; Goldberg, 2008). Despite the timing of this important work, its many contributions, and the salience of these issues to contemporary debates about urban poverty policy specifically, Black Reconstruction is infrequently cited in the extant literature on social welfare policy (Goldberg, 2008) and is less often cited in scholarship on punishment. Instead, scholars who engage Du Bois typically cite his more famous works, The Philadelphia Negro ([1899] 1995) and the Souls of Black Folks ([1903] 1989). These books each make important contributions to sociological theory, race, and criminology, but Black Reconstruction was among the first works to link social welfare administration, race, and the criminal justice system, laying the groundwork for a productive line of inquiry that would not resurface for nearly half a century.

The Freedman's Bureau closed its doors after just 7 years of operation. Its short and overlooked history is significant, not only to the formal emergence of the welfare state but also to the shape of contemporary poverty policy in the United States. Its promotion of low-wage work (sharecropping), use of punishment to modify behavior (vagrancy convictions), and the target population of its interventions (Black freedmen and their families) would foreshadow the shape of social welfare policy, debates about the efficacy of urban policy expenditures, and concerns about the welfare dependence of what would come to be termed the "urban underclass," contributing to the shape of future public policy discourses in important ways that resonated throughout the regressive 1990s and beyond.

\section{From the urban poor to the underclass}

The deep collusion between institutions of punishment and social welfare provision extend well beyond the postbellum south. Evidence of contemporary links between these twin institutions of control and social production can be found in the administration of criminal justice historically and contemporarily. By 1870, "moral regeneration" was established as the primary function of imprisonment in the United States through the drafting of the Declaration of Principles (Western 2006). Prison officials tasked with detaining prisoners were also charged with their rehabilitation. This was to be done through a system of religious ritual, moral suasion, and employment occurring inside prisons (Foucault 1977) and within community-based organizations known as prisoner aid societies. Thus, society and the very communities that prisoners came from were deemed responsible for ensuring ex-offenders were successfully integrated into their respective communities, had sufficient work opportunities to 
support their families, and were given an opportunity to contribute to society in productive ways. To accomplish this, prisoner aid societies were expected to work alongside probation officers, an occupational category overwhelmingly staffed by social workers and seminary graduates. Rehabilitation was understood as a process through which prisoners were resocialized, acclimating them to the worlds of work through prison labor, work release programs, and the moralizing effects of participation in the various organizations of civil society. Labor was not only central to the reform project but also the establishment of employment was itself a formal condition of parole (Simon 1993). This clustering of criminal justice policy initiatives has been aptly designated penal welfarism by sociologist David Garland (2001) due to its emphasis on prisoner rehabilitation through welfarist policies.

Rehabilitation was considered to be the modus operandi of the US prison system for more than a century. Law and society scholars have, however, noted that punishment strategies vary considerably by region. Using Arizona as a case study, Mona Lynch (2009) suggests the rehabilitative ideal did not have the same kinds of institutional roots in the "new sumbelt" as it did in the industrial north. Perkinson (2009) argues the recent prison boom can be viewed as more or less a southern story. Southern prisons, particularly in states like Texas, never embraced rehabilitation, have among the harshest sanctions in the nation, and have played an important but under analyzed role in the historic expansion of US prisons. Following this logic, Eason (2012) suggests the administration of criminal justice policies was significantly different in the south than in the north with fewer rehabilitative programs, more stringent sanctions, and harsher punishments for offenders.

In the north, several factors coalesced to unseat penal welfarism. Discriminatory employment practices made formal employment harder to acquire for former prisoners as northern prisons began to hold greater numbers of minorities caught up in the sweep of law and order policies (Simon 1993). Thus, as northern prisons "blackened," the acquisition of employment was no longer viewed as feasible. As a result, employment was no longer a formal requirement of parole, contributing to the erosion of support for the rehabilitative ideal.

On the welfare front, public policy discourse concerning the plight of the urban poor took on a decidedly racialized tone in the wake of the progressive 1960s (Quadagno 1994). The hard fought extension of welfare benefits to the Black working class would mark a tipping point in poverty policy and public approval of welfare state expenditures (Katz 2001; Quadagno 1994). A series of Supreme Court victories guaranteed unprecedented access for poor Black families to social safety net programs, due process in welfare hearings, and benefit administration. As a result, the Black population on welfare expanded by 333 percent between 1950 and 1970. In addition, the "illegitimacy rate" increased, with Black families representing a third of all "illegitimate" families receiving ADC benefits by 1960 (Katz 2001: 7). Thus, the protest movements of the 1960s brought renewed attention to the social condition of the Black family, launching a cottage industry of urban poverty scholarship seeking to analyze the experiences of what would be later deemed the "urban underclass."

\section{Black dependence, Black disorganization, Black deviance}

Initially arguing that social disorganization, deviance, and oppositional adaptation were the rational outgrowth racism and economic exclusion, works by scholars like Oscar Lewis, Daniel Patrick Moynihan, and Micheal Harrington were co-opted by policymakers seeking to minimize the footprint of the federal government in the lives of the urban poor (Good and Maslovski 2001). Their assertions about Black family deviance substantiated pathological theories already resonant in conservative think tanks and public policy circles (Wacquant 
2009). Pathological culture rather than the social ecology of the Black family was seen as the root cause of generational poverty and increased rates of crime. Poor people's values and cultural practices were believed to isolate them from "mainstream," White, middle-class society (Kelly, 1997). Policymakers therefore sought to target the values of the urban poor and shift their cultural practices toward the values of "mainstream" Americans. Subsequently, "treatment" for Black dependence and "non-traditional" family configurations became the interventions of choice (Schram et al., 2010; Schram, et al. 2009; Geva, 2011).

Despite resistance from prominent academics contending what some scholars deemed "dysfunctional patterns of behavior," survival strategies were employed to mitigate the structural dilemmas Black families faced (Hannerz 1969; Leibow 1967; Stack, Carol. 1974. All Our Kin. Harper \& Row). A spike in crime occurred in the 1970s, which was conflated with the civil unrest of the Black protest movements of the 1960s (Maurer, 2006). A consensus emerged among prominent academics and policymakers alike that the United State's efforts to alleviate poverty and the rehabilitative endeavors of social service programming simply did not work (Martinson 1974; Miller 1989; Quadagno 1994). Robert Martinson's influential article, "What Works? - Questions and Answers About Prison Reform," published in the 1974 edition of the Public Interest, was closely shadowed by a series of studies derisive of state-level intervention in the lives of the urban poor on the one hand and supportive of an expanded penal state on the other. While there were important distinctions between welfare and criminal justice discourses, their similarities were striking. Each presented social welfare programs as ineffective and potentially harmful (Murray, 1984). Each reasserted the locus of criminality and the origins of criminal activities within cultural rather than ecological contexts (Wilson and Herrnstein 1985). Each suggested the emphasis on rehabilitation and other forms of social support were costly, inefficient, and potentially dangerous (Wilson 1975). Finally, reminiscent of assertions from the Victorian "poverty experts" and public intellectuals of the postbellum era, each instantiated long-standing tropes linking intergenerational welfare dependence and crime to the pathology of the Black family (Kelly, 1997; Muhammad 2010; see also Culverson 2006 for an analysis of the linkages between welfare rhetoric and crime). In addition, criminal justice and social welfare actors each pushed toward a more efficient system of urban poverty management. Proponents of the "what works movement" in criminal justice administration called for scientifically based crime control techniques (Cullen and Gendreu 2001) while at the same time social welfare actors began to embrace "evidence-based practice" - the application of scientifically validated clinical interventions in mental health settings.

These seemingly objective approaches were both greatly influenced by the emergence of evidence-based medicine and called for rigorous and methodical evaluation of intervention strategies. Thus, the objection to prisoner rehabilitation and federally funded anti-poverty programs were in part scientifically based. However, as the prison census and the welfare rolls together "blackened," crime and poverty were presented as the result of individual-level characteristics resultant from the placement of marginalized populations at the shallow end of the IQ distribution or within pathological family formations (Hernstein and Murray 1994). Such discourses substantiated individualist approaches to urban poverty management that sought to address the behaviors and decision making processes of the urban poor, rather than the social ecology in which their negative social outcomes were lived out. Put differently, it was the urban poor themselves, rather than their environments, that were viewed as pathological and criminogenic. These conditions were thought to have hardened over time, and social policy intervention was therefore considered wasteful. Thus, the "what works movement" should be viewed as an extension of the culture of poverty debates and the series of policy interventions targeted toward the "underclass." 


\section{Neoliberal penality and the stratifying effects of social policy}

Policy experts called for a "new paternalism" to manage urban poverty (Mead 1997; Soss, Fording and Schram 2011) and hastened the adoption of "get tough" policies extending to criminal justice and social welfare. With the locus of welfare dependence and criminality established within individual and cultural pathology, state interventions were designed to target the decision making and culturally learned proclivities of the urban underclass. Much like initiatives in the postbellum south, the series of policies that followed led to a historic expansion in the rate and number of prisoners, making the United States the global leader in the "race to incarcerate" (Maurer 2006). The "War on Poverty" was thus unseated by the "War on Drugs," and rehabilitation by mandatory minimum sentencing, "zero tolerance policing," and other "get tough" policies to deter crime and incapacitate offenders.

On the welfare front, anti-poverty programs were themselves blamed for the emergence of the underclass, which was imagined as dependent and hyper-violent urban residents on whom social spending produced little fruit (Miller, ). The 1996 passage of PRWORA marked the transformation of the federally administered, overwhelmingly unpopular public welfare entitlement Aid to Dependent Families with Children (AFCD) into the locally administered block grant Temporary Assistance to Needy Families (TANF). Block grants consist of funding for federal programs allocated to states and local governments to use at their discretion. In effect, block grants then transfer authority from the federal to the local level by allowing states to appropriate and spend funds for federally mandated services as they see fit. TANF gave states considerable autonomy in the administration of social welfare services. The passage of PRWORA, for example, was accompanied by the institution of a federally mandated work requirement to receive welfare, a 5 -year cap on benefits eligibility, and the administration of new modes of surveillance for welfare recipients (Soss et al., 2011). States, however, had considerable autonomy in how they administered these mandates, so long as they reduced the overall welfare caseload. As such, scholars have argued that welfare reformists did not seek to reduce poverty but instead to reduce dependence.

Policymakers on both sides of the aisle trumpeted welfare reform as a success, citing the nearly 65 percent reduction in the welfare case load in just under a decade (Peck 2001). The many families pushed "off the dole" were quickly moved onto the rolls of a flexible labor sector with few benefits and unsustainable wages (Peck 2010; Wacquant 2009). In addition, street level bureaucrats' discretion and authority in the day-to-day lives of welfare recipients increased significantly (Lipski 1980; Watkins 2009). New welfare regulations disqualified large swaths of families struggling with generational poverty from the receipt of continuous welfare benefits (Katz 2001), and sanctions targeting single mothers and "dead beat fathers" were used to fleece the welfare rolls. All the while, these strategies were unevenly deployed (Schram et al., 2009) policing and indeed punishing the reproductive behaviors, leisure, and work patterns of single parent families from the inner city who were likely to be non-White, considered "non-traditional," and poor (Geva, 2011; Roberts 1997; Schram, et al. 2009; Soss, et al. 2011).

Criminal justice policy followed a similar logic. Criminal sanctions were designed and rolled out to address the demand side of drug trafficking, to crack down on "quality of life" infractions of the penal code, and were overwhelmingly focused on the arrest and incarceration of lowlevel offenders (Wacquant, 2009). These strategies have led to the over-incarceration of the urban poor, the homeless, the drug-addicted and the low-level petty offender (Wacquant 2009). These policies swelled the rolls of the US prison system, which increased sevenfold in less than 20 years. As such, the War on Drugs has been described as the most significant driver of incarceration rates in the United States (Alexander 2009; Maurer 2006). 
Arguably, these policies target the same populations in similar ways, but with notable distinctions. Wacquant (2009) suggests criminal justice and social welfare policies represent the right and left hands of an ambidextrous state. The right hand employs the police, courts, prisons, and detention centers to punitively manage unskilled laborers left vulnerable by processes of deindustrialization and labor market exclusion. Imprisonment, in this analytic, is viewed as a degradation ceremony that extends negative social capital to the overrepresented Black and Latino men who cycle in and out of prisons due to the overwhelming concentration of criminal justice intervention in low-income inner city neighborhoods. Conversely, the left hand of the state attempts to mitigate social problems through the provision of goods and services in gendered and similarly punitive ways. Poor women and their children are managed through the stigmatized social programs emblematic of the left hand, such as cash payments through TANF, the receipt of food stamps, and child care subsidies. It is important to note that beyond the dimension of social stigma for welfare recipients, there are material consequences for this social arrangement. Eligibility for welfare benefits has been tied to participation in the low-wage labor market, either through workfare arrangements for the women (Peck 2010; Wacquant 2009) or child support enforcement for the men which include the garnishment of wages, tax liens, the revocation of professional licenses, and the looming threat of future imprisonment for non-compliance (Pate 2010, Spjeldnes and Yamatani, 2013). Along with material hardship, these policies have been shown to contribute to confrontational relationships and the dissolution of already fragile family arrangements.

Scholars disagree on the prison's role and consequence. However, there is general agreement that the clientele of the US prison system are overwhelmingly concentrated in low-income communities of color and that the prison, as an institutional arrangement based on policy decision making, has both classifying and stratifying effects. Today, 60 percent of Black, inner city high school dropouts and 30 percent of those who do graduate will be arrested at some point during their life course (Western 2006). More insidiously, nearly a quarter of all African-American children have an incarcerated parent, with the increased incarceration of African-American women shown to account for nearly a third of all new foster care placements in the United States (Roberts, 2002). Finally, mass incarceration has been shown to not just increase the economic disadvantage of the families affected by it but also to increase the incidence of negative mental health outcomes in mothers and their children as well (Wildeman 2009). Thus, the prison can be understood as a punitive institution with extra penological effects (Wacquant 2009). In the same way, social welfare policy can be seen as a social institution with punitive, disciplinary, and regulatory effects (Piven and Cloward 1993; Soss et al., 2011). Both of which extend disadvantage across a host of social domain and ossify the precarious positions of racialized groups within the social hierarchy.

\section{Conclusions}

While the rates of incarceration and the scale of social welfare retrenchment is novel to the current age, there is considerable continuity between old and new crime control and social welfare interventions. The ways in which we currently "govern social marginality" (Beckett and Western 2001) have resonance with long-standing techniques to discipline and regulate Black workers, dating back at least to the postbellum south. Contemporary critiques of the "nanny state" and the "entitlement society" used to limit the extension of benefits to the urban poor, and aversions to the "redistribution of wealth" from the "makers" to the "takers" of the contemporary political economy resonate with assertions from Victorian "poverty experts" 
about the incapacitating nature of the "dole," postbellum assertions about the readiness of White paupers and Black slaves for "economic freedom," and poverty discourses discouraging state intervention in the lives of the urban poor. In addition, there is significant continuity between the tough-on-crime policies that target petty drug offenders residing in the low rent, high unemployment districts of the postindustrial city, and vagrancy convictions of the postbellum south.

This is not to suggest that mass incarceration is a renewed, albeit muscularized technique of social control made in the image of slavery. The Jim Crow regime, for example, was a regional phenomenon, contained within southern states and states bordering the south. Furthermore, I have demonstrated that disproportionate incarceration rates are not novel. However, the conflation of today's punishment trends with the back breaking labor of the chain gang, and southern peonage arguably diminishes the atrocities of the postbellum period (Foreman, 2012). In addition, while a strong case can be made for a profit motive in the emergence of privately managed, publicly funded charter schools, health-care organizations, mental health services, and institutions of higher education, prisons are not yet large generators of private revenue when compared with other institutions and are arguably among the least privatized institutions in the business of managing marginalized populations. Rather, the hallmark of neoliberalism in the twin institutions of punishment and social welfare provision is not in the novelty of a "hollowed out state," or the advent of "small government" but in the emergence of big government in the lower reaches of the postindustrial economy, and a formal reconfiguration and re-regulation of markets to increase the upward mobility of already advantaged populations and conversely the stagnation of disadvantaged ones (Wacquant, 2012b).

Following Wacquant's (2012b) admonition, scholars must "reconnect social and penal policies and treat them as two variants of poverty policy" in order to "grasp the new politics of marginality" (p. 237). This new marginality, according to Beckett and Western (2001), is governed through mass incarceration and public welfare policy, acting as a single (or unified) policy regime. As a remaking of government, rather than another mode of social control, the punishment of poverty (and race) in the neoliberal age has both stratifying and classifying effects (see Wacquant, 2012b), situating groups within a social hierarchy and creating new ways of being in the social world. I have demonstrated these processes through the punishment of race and poverty during the postbellum period, which I argue underscored the ways in which freed slaves were understood and justified the policies of the Freedman's Bureau to discipline Black workers. This was achieved through the mitigation and enforcement of labor contracts with southern planters. Sanctions for violations of these contracts included convictions under vagrancy laws, at once swelling the roles of the postbellum criminal justice system while constituting the Black vagrant as dangerous and dependent in the public imagination. During the post-welfare era, I have demonstrated the ways in which this construction justified welfare reform initiatives that valorized work for its disciplinary effects and punitive responses to minor infractions of the penal code. Thus, how we punish and provide for our most vulnerable populations has had important implications for the ways in which we conceptualize the role of the state and the ways in which race, poverty, and criminality are embodied and understood.

The distribution of goods and services through bureaucratic processes, in this case through the administration of social welfare policies, reinforce the positions of cultural categories and contributes to the classification of social actors as both consumers of goods and services and as bearers of specific social outcomes. Therefore, the concentration of urban disadvantage and the subsequent intervention strategies the state employs to ameliorate social problems not only differentially impacts the material realities of racialized and otherwise dishonored cultural categories (stratification) but also contributes to the ways in which these groups are 
understood by political decision makers (classification) and, perhaps more importantly, to the ways in which these groups understand themselves (subjectivity). To adequately capture these race-based, gendered, political, and economic processes, social scientists must break away from their disciplinary silos, as social problems simply do not come in neat disciplinary packages (Nyden et al., 2012). To this end, promising research examining the sociological implications of race, social welfare, and criminal justice policy has been conducted by a contingent of social scientists whose work offers a bridge across disciplinary divides. For example, Forrest Stuart (2011) examines the welfarist logics that animate broken windows policing strategies on LA's skid row, while John Eason (2012) highlights the importance of stigma and the sociopolitical context of the rural prison town in prison citing. Robert Fairbanks (2009 and 2011) documents the emergence of a shadow welfare state in addictions treatment for former prisoners, highlighting the centrality of paraprofessionals in social welfare provision, while Alison McKim (2008) examines the "therapeutic governance" of the gendered and racialized subjects of substance abuse treatment programs for formerly incarcerated women. Megan Comfort's (2008, 2012) work documents the dual role of the prison in the lives of poor Black and Latino couples. Her respondents report that the prison is at once a domestic satellite and hub of social service provision, a place of reflection and growth, and a harsh cite of punishment. Finally, Waverly Duck's (2012) program of research untangles the web of social welfare provision, changes in the political economy, predatory housing policies, and culture in the constitution of the urban precariat - the precariously housed, precariously employed, and precariously protected racialized and impoverished resident of the postindustrial city. These studies demonstrate the complex interaction between race, social welfare policy, culture, and punishment. As such, they have far-reaching implications for social theory, social policy, and the practice of social service and criminal justice administration.

Research on race, punishment, and social welfare policy should therefore not be the express domain of scholars studying race and ethnic relations, urban sociology, criminology, socio-legal phenomena, or the welfare state, publishing in the isolation of their respective sub-disciplines. Given the effects of incarceration across multiple domains and the long-standing influence of race on public policy, these factors should be taken up by political sociologists and political scientists, urban historians, family studies scholars, social work researchers, economists, and economic sociologists committed to interdisciplinary scholarship as well. This big tent approach will not only enhance our understanding of the role, scope, and force of punishment, race, and social welfare in contemporary urban (and rural) life but also a diverse methodological and theoretical approach may contribute to innovative solutions to our new American dilemma the rise of hyper-incarceration and the concentration of social, political, and economic disadvantage.

\section{Acknowledgement}

I would like to thank David Brunsma and David Embrick for their patience throughout the review process and the anonymous reviewers at Sociology Compass for their careful and critical insights. I would also like to thank Janice Williams Miller in particular for tirelessly reading drafts of every paper I can ever remember writing. She is both my biggest supporter and my harshest critic.

I am grateful for the research support from multiple sources, including the US Department of Housing and Urban Development (grant no. H-21637G), the American Society of Criminology Graduate Minority Fellowship, the Robert McCormick Foundation, PolicyLink, the Center for Urban Research and Learning, the Community Stewards Award Program, and the Graduate School at Loyola University Chicago. 


\section{Short Biography}

Reuben Jonathan Miller is an Assistant Professor of Social Work at the University of Michigan. His dissertation, "Halfway Home: Race, Reentry, and the Micro Politics of Personal Transformation," is an ethnographic study of prisoner reentry programing in a large Midwestern city. He has authored or coauthored papers on neoliberal penality, social welfare, incarceration, and public health policy. In addition, he is the co-editor of a special edition of the Journal of Poverty: Innovations in Social, Political and Economic Inequalities and the Rutledge Handbook on Poverty in the United States. He is the recipient of a HUD Doctoral Dissertation Grant (H-21637G) and fellowships from the Robert McCormick Foundation and the American Society of Criminology. He holds a BA from Chicago State University and an AM from the University of Chicago - School of Social Service Administration.

\section{Notes}

${ }^{\star}$ Correspondence address: Reuben Jonathan Miller, Department of Sociology, Loyola University, Chicago, IL, USA. E-mail: rmiller2@luc.edu

1 There are important empirical exceptions that in some ways contradict the "hallowed out state" thesis popular in critiques of US style neoliberalism. In criminal justice, for example, Phelps (2011) finds that there was no real decline in statesponsored rehabilitative programming for prisoners until well into the 1990s, despite tough-on-crime rhetoric. Miller (forthcoming) highlights the dramatic expansion of community-based prisoner reentry services and their salience in the lives of the urban poor from the moment of welfare reform through the passage of the second chance act. Fox (1999), Fairbanks (2011), McKim (2008), and others detail the ascendance of therapeutic modalities in prisons, reentry services, and other correctional programs designed to modify behaviors and address the meaning making capacities of prisoners and former prisoners. In social welfare, Gottschalk (2000) details the emergence of what she terms the "shadow welfare state," while Fairbanks (2009) demonstrates the considerable expansion of welfare services and the overreliance of the state on private community-based actors providing substance abuse treatment - what he terms recovery house entrepreneurs. Such findings lead Wacquant (2012b) to argue that the state has not been hallowed out but instead reconfigured.

\section{References}

Alexander, M. 2009. The New Jim Crow: Mass Incarceration in an Age of Color Blindness. New York: The New Press.

Beaumont, G., F. Lieber and A. Tocqueville. 1833. On the Penitentiary System in the United States and its Application in France. PDF Retrieved on August 6, 2010 from http://www.archive.org/details/onpenitentiarysy00beauuoft

Beckett, K. and B. Western. 2001. Governing Through Social Marginality: Welfare, Incarceration, and the Transformation of State Policy. Punishment and Society 3 (1): 43-59.

Bobo, L.D. and V. Thompson. 2010. Racialized Mass Incarceration: Poverty, Prejudice, and Punishment. Pp. 322-355 in Doing Race: 21 Essays for the 21st Century, edited by Hazel R. Markus and Paula Moya. New York: Norton.

Comfort M. 2012. "'It was Basically College to Us': Poverty, Prison, and Emerging Adulthood.” The Journal of Poverty: Innovations on Social, Political and Economic Inequalities 16 (3): 308-322.

Comfort M. 2008. Doing Time Together: Love and Family in the Shadow of the Prison. The University of Chicago Press.

Cullen F., and P. Gendreu. 2001. "From Nothing Works to What Works: Changing Professional Ideology in the 21st Century." The Prison Journal, 81:313-338

Du Bois, W.E.B. [1935] 1999. Black Reconstruction in America, 1860-1880. Durham, NC: Duke University Press.

Du Bois, W.E.B.[1903] 1989. The Souls of Black Folk. New York, NY: Bantam Press.

Du Bois, W.E.B. [1899] 1995. The Philadelphia Negro: A Social Study. Philadelphia, PA: University of Pennsylvania Press.

Duck, W.O. 2012. "An Ethnographic Portrait of a Precarious Life: Precarious Living: Getting by on Even Less.” Annals of the American Academy of Political and Social Science 642:139-151.

Eason, J. 2012. "Extending the Hyper Ghetto: Toward a Theory of Punishment, Race, and Rural Disadvantage. The Journal of Poverty: Innovations on Social, Political and Economic Inequalities 16(4):274-295.

Fairbanks II, R.P. 2011. “The Illinois Reentry Imperative: Sheridan Correctional Center as National Model.” Carceral Notebooks 6: 175-200. 
Fairbanks II, R.P. 2009. How it works: Recovering Citizens in Post-Welfare Philadelphia. Chicago: The University of Chicago Press.

Farmer-Kaiser, M. 2004. “Are They Not in Some Sorts Vagrants?' Gender and the Efforts of the Freedmen's Bureau to Combat Vagrancy in the Reconstruction South.” Georgia Historical Quarterly 88:1:25-49.

Feeley, M. and J., Simon 1992. "The New Penology: Notes on the emerging strategy of corrections and its implication." Criminology, 30 (4): 449-474.

Fox, K.J. 1999. Reproducing Criminal Types: Cognitive Treatment for Violent Offenders in Prison. The Sociological Quarterly, 40(3).

Foucault, M. 1977. Discipline and Punish: The Birth of the Prison. New York, NY: Random House.

Foreman, J. 2012. "Racial Critiques of Mass Incarceration: Beyond the New Jim Crow." New York University Law Review, 87 (1): 21-69.

Garland, D. 2001. The Culture of Control: Crime and Social Order in Contemporary Society. Chicago, University of Chicago.

Gilens, M. 1999. Why Americans Hate Welfare: Race, Media, and the Politics of Anti Poverty Policy. Chicago: London: University of Chicago Press.

Geva, D. 2011. Not Just Maternalism: Marriage and Fatherhood in American Welfare Policy. Social Politics, 18:1:24-51.

Goldberg, C.A. 2008. Citizens and Paupers: Relief, Rights, and Race, from the Freedman's Bureau to Workfare. Chicago: London. University of Chicago Press.

Goode J. and J. Maslovski. (Eds). 2001. New Poverty Studies: The Ethnography of Power, Politics, and Impoverished People in the United States.

Gorman, T.M. 1997. "Back on the Chain Gang: Why the Eighth Amendment and the History of Slavery Proscribe the Resurgence of Chain Gangs." California Law Review, 85:2:441-478.

Gottschalk, M. 2000. The Shadow Welfare State: Labor, Business, and the Politics of Health Care in the United States. Ithaca: Cornell University Press.

Hannerz, U. 1969. Soulside. New York: Columbia University Press.

Haney, L. 2010. Offending Women: Power, Punishment, and the Regulation of Desire. Berkeley: Los Angeles: University of California Press.

Harcourt, B. 2011. Illusion of Free Markets: Punishment and the Illusion of Natural Order. Chicago, IL: University of Chicago Press.

Harrington, M. 1962. The Other America: Poverty in the United States. New York: Penguin.

Harvey, D. 2007. A brief History of Neoliberalism. New York: Oxford University Press.

Hernstein, R., and C. Murray. 1994. The Bell Curve: Intelligence and Class Structure in American Life. New York: Free Press.

Hollandsworth, J.G. 2008. "Black Confederate Pensioners After the Civil War." Mississippi History Now, Retrieved on August 6, 2010 from http://mshistory.k12.ms.us/articles/289/black-confederate-pensioners-after-the-civil-war

Katz, M. 2001. The Price of Citizenship: Redefining the American Welfare State. University of Pennsylvania Press.

Kelly, R.D.G. 1997. Yo Mama's Dysfunktional!: Fighting the Culture Wars in Urban America. Beacon Press.

Kern, W.S. 1998. Current welfare reform: A return to the principles of 1834. Journal of Economic Issues, 32(2), 427-432.

Lewis, Oscar. 1966. "The Culture of Poverty.” Scientific American 215:19-25

Liebow, Elliot. 1967. Tally's Corner: A Study of Street Corner Negro Men. Boston: Little Brown Company.

Lieberman, Robert C. 1998. Shifting the Color Line: Race and the American Welfare State. Cambridge: Harvard University Press.

Lipski, Michael. 1980; Street Level Bureaucracy: Dilemmas of the Individual in Public Service. New York, NY. Russell Sage Foundation.

Logue, Larry M. and Peter Blanck. 2008. "Benefit of the Doubt: African-American Civil War Veterans and Pensions." Journal of Interdisciplinary History 38:3:377-399.

Lurigio, A, T Lyons, L Brookes, and T Whitney. 2010. Illinois Disproportionate Justice Impact Study. Center for Health and Justice at TASC on behalf of the Illinois Disproportionate Justice Impact Study Commission. Retrieved on March 30, 2011 from http://www.centerforhealthandjustice.org/DJIS_FullReport_1229.pdf

Lynch, M .2009. Sunbelt Justice: Arizona and the Transformation of American Punishment. Stanford University Press.

Mancini, Matthew J. 1978. "Race, Economics, and The Abandonment of Convict Leasing." The Journal of Negro History, 63:4:339-352.

Martin, Kathleen. 2008. Hard and Unreal Advice: Mothers, Social Science and the Victorian Poverty Experts, New York, NY: Palgrave Macmillan.

Martinson, R. 1974. What works? - Questions and Answers about Prison Reform. The Public Interest 22-54.

Maurer, M. 2006. Race to Incarcerate. The New Press, New York; NY.

Mead, L. 1997. The New Paternalism: Supervisory Approaches to Poverty. Brookings Institute Press.

McKim, A. 2008. "Getting Gut Level: Punishment, Gender, and Therapeutic Governance." Gender and Society, 22: 303-323. 
Miller, J.G. 1989. Is it True that Nothing Works? Washington Post retrieved on February 13, 2011 from http://www. prisonpolicy.org/scans/rehab.html

Miller, R. Forthcoming. "Strange Affinities: Race, Religion, and the Punishment Entrepreneurs of the U.S. Carceral Field" in the The Routledge Handbook on Poverty in the United States. Edited by Stephen Haymes, Reuben Jonathan Miller and Maria Vidal de Haymes. New York: London: Routledge Press.

Moynihan, D.P. 1965. The Negro Family: The Case for National Action. Washington, D.C.: U.S. Department of Labor. Muhammad, K.G. 2010. The Condemnation of Blackness: Race, Crime, and the Making of Modern Urban America, Cambridge, MA: Harvard University Press, Cambridge, MA.

Murray, C. 1984. Losing Ground: American Social Policy, 1950-1980. HaperCollins Publishing.

Neubeck, K.J. and N. Cazenave. 2001. Welfare Racism: Playing the Race Card Against America's Poor. New York: Routledge.

Nkansah-Amankra, S., S. Agbanu and R. Miller. 2013. "Disparities in health, poverty, incarceration and social justice among racial groups in the United States: A critical review of evidence of close links with neoliberalism." International Journal of Health Services, 43(2): 217-240.

Nyden, P., L. Hossfeld, and G. Nyden. 2012. Public Sociology: Research, Action, Change. Sage Publications.

O'Connor, J. 1973. The Fiscal Crisis of the State. St. Martin's Press.

O'Connell, A. 2009. "Building Their Readiness for Economic "Freedom": The New Poor Law and Emancipation." Journal of Sociology and Social Welfare 36(2)85-10.

O’Connell, A. 2010. "A Genealogy of Poverty: Race and the Technology of Population.” Critical Social Work 11:2.

Pate, D. 2010. "Life After PRWORA: The Involvement of African-American Fathers with welfare-reliant Children and the Child Support Enforcement System.” In Social Work with African American Males: Health, Mental Health, and Policy. Editor: Waldo Johnson.Publisher:Oxford Press.

Piven, F.F., \& Richard Cloward. 1993. Regulating the Poor: The Functions of Public Welfare. New York: Vintage Books. Peck, J. 2010. Workfare States. London: Guilford Press.

Peck, J., and N. Theodore. 2009. "Carceral Chicago: Making the Ex-Offender Employability Crisis. International Journal of Urban and Regional Research. 32(2):251-281.

Peck, J. 2010. Constructions of Neoliberal Reason. Oxford University Press.

Perkinson, R. 2009. Texas Tough: The Rise of America's Prison Empire. Metropolitan Books.

Phelps, M. 2011. "Rehabilitation in the Punitive Era: The Gap between Rhetoric and Reality in U.S. Prison Programs." Law \& Society Review, 45(1): 33-68.

Quadagno, J. 1994. The Color of Welfare. Oxford: Oxford University Press.

Roberts, D. 1997. Killing the Black Body: Race, Reproduction and the Meaning of Liberty. New York: Vintage.

Roberts, D. 2002. Shattered Bonds: The Color of Child Welfare. Basic: Civitas Books. New York, NY.

Sampson, R.J., and C. Loeffler. 2010. "Punishment's place: The Local Concentration of Mass Incarceration.” Daedalus Summer 20-31.

Schram, S.F, J. Soss, R.C. Fording and L. Houser. 2010. "The third level of US Welfare Reform: Governmentality under Neoliberal Paternalism." Citizenship Studies 14: 6, 739-754

Schram, S.F., J. Soss, R.C. Fording, and Linda Houser. 2009. "Deciding to discipline: Race, Choice, and Punishment at the Frontlines of Welfare Reform.

Simon, J. (1993) Poor Discipline: Parole and the Social Control of the underclass, 1890-1990. Chicago, IL: University of Chicago Press.

Skocpol, T. 1992. Protecting Mothers and Soldiers: The Political Origins of Social Policy in the United States. Boston: Harvard University Press.

Soss J., R.C. Fording and S.F. Schram. 2011. Disciplining the Poor: Neoliberal Paternalism and the Persistent Power of Race. Chicago: University of Chicago Press.

Spjeldnes S., and Yamatani, H. 2013. "Child Support Conviction and Recidivism: A Statistical Interaction Pattern by Race." Paper Presented at the Annual Conference of the Society for Social Work Research.

Stuart, F. 2011. "Race, Space, and the Regulation of Surplus Labor: Policing African-Americans in Los Angeles' Skid Row." Souls: A Critical Journal of Black Politic, Culture and Society, 13 (2): 197-212.

Taylor, K.Y. 2009. "W.E.B. Du Bois Black Reconstruction in America.” International Socialist Review. 57.

U.S. Census Bureau. 1860. Preliminary Report on the 8th Census. Retrieved on August 7, 2010 from http://www2.census. gov/prod2/decennial/documents/1860e-03.pdf

Wilson, J.Q. 1975. Thinking about Crime. New York, NY. Vintage.

Wilson, J.Q. and Richard Herrnstein. 1985. Crime and Human Nature: The Definitive Study of the Causes of Crime. New York: Simon and Schuster.

Wacquant, L.J.D. 2012a. "The Wedding of Workfare and Prisonfare in the 21st Century." The Journal of Poverty 16 (3): 236-249.

Wacquant, L.J.D. 2012b. Toward a Historical Anthropology of Actually Existing Neoliberalisim. Social Anthropology

Wacquant, L.J.D. 2001. “Class, Race and Hyperincarceration in Revanchist America.” Daedalus 140 (3): 74-90. 
Wacquant, L.J.D. 2009: Punishing the Poor: The Neoliberal Government of Social Insecurity. Durham, NC:

Watkins-Hayes, C. 2009. The New Welfare Bureaucrats: Entanglements of Race, Class, and Policy Reform. Chicago: University of Chicago Press.

Western, B. 2006. Punishment and Inequality in America. New York: Russell Sage Foundation.

Wildeman, C. 2009. "Parental Imprisonment, the Prison Boom, and the Concentration of Childhood Disadvantage." Demography, 46: 265-280. 